\title{
Response of Nebraska Horseweed (Conyza canadensis) Populations to Dicamba
}

\author{
Roberto J. Crespo ${ }^{1}$, Mark L. Bernards ${ }^{1,2}$, Greg Kruger ${ }^{3}$, Donald Lee ${ }^{1} \&$ Robert Wilson $^{4}$ \\ ${ }^{1}$ Department of Agronomy and Horticulture, University of Nebraska-Lincoln, United States \\ ${ }^{2}$ School of Agriculture, Western Illinois University, Macomb, IL, United States \\ ${ }^{3}$ West Central Research and Extension Center, University of Nebraska, North Platte, NE, United States \\ ${ }^{4}$ Panhandle Research and Extension Center, University of Nebraska, United States \\ Correspondence: Roberto J. Crespo, Department of Agronomy and Horticulture, University of Nebraska-Lincoln, \\ United States. E-mail: rcrespo@huskers.unl.edu, rojacre@yahoo.com.ar
}

\author{
Received: February 1, 2013 Accepted: March 18, 2013 Online Published: April 15, 2013 \\ doi:10.5539/jas.v5n5p158 URL: http://dx.doi.org/10.5539/jas.v5n5p158
}

\begin{abstract}
Dicamba-resistant soybeans are being developed to provide an additional herbicide mechanism-of-action for postemergence weed control in soybean. Numerous broadleaf species, including horseweed, have evolved resistance to glyphosate. It is anticipated that dicamba will be used by farmers as a primary tool to manage these weeds. Studying and understanding variability in horseweed response to dicamba will aid in developing appropriate risk management strategies to extend the utility of the dicamba-resistance technology. Horseweed plants from ten Nebraska populations were treated with one of nine doses of dicamba in greenhouse experiments. At 28 days after treatment (DAT) visual injury estimations were made and plants were harvested to determine dry weight. There was a three-fold difference in the $\mathrm{I}_{90}\left(90 \%\right.$ visual injury estimate) between the least $\left(638 \mathrm{~g} \mathrm{ha}^{-1}\right)$ and most $\left(205 \mathrm{~g} \mathrm{ha}^{-1}\right)$ susceptible populations. Two plants from five populations were observed for an additional three months. No plants treated at doses above $280 \mathrm{~g} \mathrm{ha}^{-1}$ survived to set seeds. These results suggest that maintaining use doses of $560 \mathrm{~g} \mathrm{ha}^{-1}$ or greater may fully control horseweed populations from Nebraska and minimize the risk of plants surviving to set seed, in addition to practicing other proven herbicide-resistance management strategies.
\end{abstract}

Keywords: Canada fleabane, dose-response, herbicide resistance, marestail, risk assessment

\section{Introduction}

In the U.S., $90 \%$ of the soybean [Glycine max (Merr.) L.] acreage is planted to glyphosate-resistant varieties (Johnson, Strom, \& Grillo, 2008). The exclusive use of glyphosate for burndown and postemergence weed control in soybean resulted in the selection of the first glyphosate resistant horseweed population in Delaware in 2000 (VanGessel, 2001). Since 2000, glyphosate-resistant horseweed populations have been reported in 16 U.S. states as well as Brazil, China, Spain, and the Czech Republic (Heap, 2013). Glyphosate-resistant horseweed is problematic in soybean fields because few herbicides that control it are labeled for postemergence use in soybean. In addition, horseweed populations have also evolved resistance to other herbicide modes-of-action, including acetolactate synthase (ALS) inhibitors, cell membrane disrupters, photosystem I inhibitors, and photosystem II inhibitors (Heap, 2013). Horseweed populations that are resistant to multiple herbicide mechanisms of action are particularly difficult to manage (Kruger, Davis, Weller, \& Johnson, 2010). In no-tillage cropping systems dicamba and 2,4-D are effective and economical for controlling horseweed prior to planting (VanGessel, 2001), but are not available for use immediately prior to planting nor after soybean has emerged.

Transgenic technologies conferring herbicide-resistance to dicamba or 2,4-D are being developed to complement glyphosate-resistance traits in corn, soybean and cotton (Johnson et al., 2010; Peterson et al., 2009; Simpson et al., 2009). Dicamba (3,6-dichloro-2-methoxybenzoic acid) is a synthetic auxin herbicide that controls a number of important broadleaf weeds in cereal crops. The gene encoding an enzyme from Pseudomonas malthopilia that metabolically inactivates dicamba was isolated and inserted into soybean. Plants expressing the trait tolerate 2800 $\mathrm{g} \mathrm{ha}^{-1}$, ten times a typical dose of $280 \mathrm{~g} \mathrm{ha}^{-1}$ commonly used in corn (Behrens et al., 2007). There are 29 weed biotypes that have evolved resistance to synthetic auxin herbicides (Heap, 2013), and only five species are reported to be resistant to dicamba: common lambsquarter (Chenopodium album L.) in New Zealand, common hempnettle 
(Galeopsis tetrahit L.) in Canada, kochia (Kochia scoparia L.) in MT, NE, ND and ID, prickly lettuce (Lactuca serriola L.) in WA, and wild mustard (Sinapis arvensis L.) in Canada and Turkey (Heap, 2013).

With the potential commercialization of dicamba-resistant soybean, agriculture has the opportunity to steward the new technology in a way that will not repeat the lost efficacy resulting from the evolution of glyphosate-resistant, ALS-inhibitor resistant and other herbicide resistant weeds. In a survey sent to weed science scientists, agronomists and farmers asking them to assess the risk likelihood of various weeds evolving resistance to dicamba after commercialization of dicamba-tolerant soybean, $25 \%$ rated horseweed as having a high risk and $46 \%$ rated horseweed a moderate risk (Crespo, Bernards, \& Peterson, 2012). Managing for pesticide resistance ideally is proactive, not reactive. To best implement proactive resistance management, factors such as potential selection pressure resulting from the herbicide use pattern and species variability should be identified, classified and systematically assessed. Given the widespread distribution of glyphosate resistant horseweed populations in eastern Nebraska (Heap, 2013), greenhouse bioassays using dose-response methodology represents a tool to monitor baseline levels of susceptibility and variability in response to dicamba dose across horseweed populations in Nebraska. Therefore, a greenhouse bioassay was conducted to monitor the baseline susceptibility of ten southeastern Nebraska horseweed populations to dicamba dose in terms of biomass production and visual injury. In addition, we collected preliminary information on long term survival and seed production of dicamba-treated horseweed plants.

\section{Materials and Methods}

\subsection{Population Sampling}

Seed of ten horseweed populations were collected from seven southeastern Nebraska counties (Butler, Cass, Lancaster, Otoe, Saunders, Seward and York) in September and October, 2009. The seed was collected from roadside populations and populations present in corn and soybean fields. Each horseweed population was a composite of 40 or more plants. Horseweed seed was cleaned and stored at $4^{\circ} \mathrm{C}$.

\subsection{Plant Growth and Dicamba Application}

The experiments were conducted in the greenhouses located on East Campus of the University of Nebraska-Lincoln in Lincoln, Nebraska. Supplemental lighting in the greenhouse provided a $15 \mathrm{~h}$ photoperiod. The day/night temperatures were $24 \pm 2{ }^{\circ} \mathrm{C}$ and $19 \pm 3{ }^{\circ} \mathrm{C}$, respectively. Seed from each horseweed population was planted in potting mix (Miracle-Gro Moisture Control Potting Mix, The Scotts Company LLC, OH, USA) in 50 by 35 by $10 \mathrm{~cm}$ black plastic flats. Flats were watered daily to ensure adequate soil moisture. Two weeks after planting three healthy seedlings (three to five leaves) were transplanted into a 10 by 10 by $12.5 \mathrm{~cm}$ black plastic pot. Plants were watered as needed. Prior to treatment with herbicide, seedlings were thinned to one plant per pot.

Plants were treated when horseweed rosettes were 8 to $12 \mathrm{~cm}$ wide (12 to 16 days after transplanting). Herbicide treatments were applied in a research chamber sprayer (DeVries Mfg. Corp., Hollandale, MN, USA) using a TP8001E flat-fan nozzle tip (Spraying Systems Co., North Avenue, Wheaton, IL, USA), 190 L ha $^{-1}$ carrier volume and a spray pressure of $207 \mathrm{kPa}$.

\subsection{Dose-Response Bioassay}

A dicamba dose-response bioassay with nine dicamba doses was conducted for each horseweed population and was repeated twice in time for a total of two runs. The experiment was arranged in a randomized complete block design with seven replications. The dicamba doses were $0,8,17,35,70,140,280,560$ and $1120 \mathrm{~g}^{\text {ae ha }} \mathrm{a}^{-1}$ of dicamba (diglycolamine salt of 3,6-dichloro-2-methoxybenzoic acid) (Clarity, $480 \mathrm{~g} \mathrm{~L}^{-1}$, Herbicide, BASF Corporation, NC, USA).

\subsection{Data Collection and Statistical Analysis}

Visual injury estimates of treated plants were based on growth suppression and epinastic effects compared to the nontreated control plants. Estimates were recorded at 7, 14, 21 and 28 days after treatment (DAT) on a scale of 0 (no injury) to 100 (dead plants). At 28 DAT, plants were cut at the base of the rosette, oven dried for 2 days in a forced air dryer at $65^{\circ} \mathrm{C}$, after which dry weight was recorded for individual plants. Also, two untreated replications were harvested the day of the herbicide application, dried and weighed to calculate the average weight of plants at the time of treatment.

In the second run of the experiment we conducted a preliminary study to evaluate the long term survival and potential to produce seed as affected by dicamba dose. Two replications of five horseweed populations (populations 18, 20, 32, 39 and 44) were grown for 228 days. Plant survival (defined as the plant having green tissue) was recorded at 28, 56, 112 and 168 DAT. At 228 DAT, the seed of each plant was individually harvested. 
For each plant with adequate seed production, two subsamples of 100 seeds each were weighed and then averaged. The number of seed per plant was estimated by dividing the total weight of seed by the average 100 -seed weight. Two-way ANOVA for the number of seed per treatment for each population was performed using SigmaPlot 11.0 (Systat Software, Inc., IL, USA). Means were separated using an LSD procedure with $\alpha=0.05$.

Visual injury estimate and dry weight data were analyzed using a nonlinear regression model with the $d r c$ package in R statistical software (R Foundation for Statistical Computing, Vienna, Austria). Dose-response models were constructed using a four parameter log-logistic equation:

$$
y=c+(d-c / 1+\exp (b(\log x-\log e)))
$$

where $y$ is the response (e.g., visual injury estimate), $e$ is the effective dose to reach the $50 \%$ growth reduction $\left(\mathrm{GR}_{50}\right)$ or injury estimation $\left(\mathrm{I}_{50}\right)$ and is also the inflection point, $b$ is the slope at $e, c$ is the lower limit and $d$ is the upper limit of the model. The dicamba dose needed to achieve the 50, 80 and $90 \%$ dry weight reduction $\left(\mathrm{GR}_{50}\right.$, $\left.\mathrm{GR}_{80}, \mathrm{GR}_{90}\right)$ and visual injury $\left(\mathrm{I}_{50}, \mathrm{I}_{80}, \mathrm{I}_{90}\right)$ estimates were calculated. The relative level of resistance were expressed by calculating the R:S (Resistant : Susceptible) ratios between the I or GR values of less susceptible populations and the I or GR values of the most susceptible population.

\section{Results}

\subsection{Effect of Dicamba on Horseweed}

The effective dose necessary to achieve the $\mathrm{I}_{90}$ varied 3.1 fold between the least and most susceptible horseweed populations (Table 1). Population 44 was the least susceptible and population 32 was the most susceptible to dicamba based on visual injury estimates for both $\mathrm{I}_{50}$ and $\mathrm{I}_{90}$ (Table 1 and Figure 1). A use dose of $560 \mathrm{~g} \mathrm{ha}^{-1}$ was calculated to provide greater than $90 \%$ injury of all populations evaluated except population 44 , for which $90 \%$ control required $638 \mathrm{~g} \mathrm{ha}^{-1}$.

Table 1. Visual injury estimate regression parameters, $\mathrm{I}_{50}, \mathrm{I}_{80}$ and $\mathrm{I}_{90}$ dicamba doses $\left(\mathrm{g}\right.$ ae ha $\left.{ }^{-1}\right)$, and standard errors (SE) at 28 DAT for ten horseweed populations from Nebraska. Regression parameters were estimated using a log-logistic equation (Equation 1)

\begin{tabular}{|c|c|c|c|c|c|c|c|}
\hline \multirow{3}{*}{$\begin{array}{l}\text { Population } \\
3\end{array}$} & \multicolumn{3}{|c|}{ Regression parameters ${ }^{a}$} & \multirow{2}{*}{\multicolumn{2}{|c|}{$\mathrm{I}_{80}( \pm \mathrm{SE})$}} & \multirow{2}{*}{\multicolumn{2}{|c|}{$\mathrm{I}_{90}( \pm \mathrm{SE})$}} \\
\hline & \multirow{2}{*}{$\begin{array}{l}b \\
-1.1\end{array}$} & \multicolumn{2}{|c|}{$\mathrm{I}_{50}( \pm \mathrm{SE})$} & & & & \\
\hline & & 50 & (6) & 178 & $(30)$ & 376 & (89) \\
\hline 6 & -1.2 & 41 & (7) & 129 & (27) & 252 & (76) \\
\hline 7 & -1.1 & 30 & (4) & 108 & (21) & 230 & (62) \\
\hline 18 & -0.9 & 52 & (12) & 228 & (79) & 539 & (263) \\
\hline 20 & -1.1 & 31 & (4) & 112 & (21) & 236 & (64) \\
\hline 32 & -1.1 & 27 & (3) & 97 & (14) & 205 & (42) \\
\hline 39 & -1.3 & 38 & (4) & 114 & (17) & 219 & (45) \\
\hline 44 & -0.9 & 61 & (16) & 268 & (99) & 638 & (335) \\
\hline 52 & -1.1 & 40 & (5) & 147 & (29) & 317 & $(90)$ \\
\hline 62 & -1.0 & 36 & (5) & 144 & (29) & 325 & (87) \\
\hline $\mathrm{R}: \mathrm{S}$ & & 2.3 & & 2.8 & & 2.9 & \\
\hline
\end{tabular}

${ }^{\text {a }}$ Regression parameters were estimated using a four parameter log-logistic equation (Equation 1 ), where $c$ represents the lower limit ( $0=$ no injury), $d$ represents the upper limit $(100=$ plant death $), b$ represents the slope of the line at the inflection point, and $e$ represents the herbicide dose necessary to provide $50 \%$ injury $\left(\mathrm{I}_{50}\right)$.

When the response to dicamba dose was calculated based on dry weight reduction, population 44 was the least susceptible at both $\mathrm{GR}_{50}$ and $\mathrm{GR}_{90}$ (Table 2). The most susceptible population differed from the visual injury estimates (population 32), and also varied between $\mathrm{GR}_{50}$ (population 62) and $\mathrm{GR}_{90}$ (population 52). The dicamba doses required to achieve $\mathrm{GR}_{50}$ or $\mathrm{GR}_{90}$ was less than the doses required for comparable visual injury estimations $\left(I_{50}\right.$ and $I_{90}$ ). However, the variation between most and least susceptible populations was similar for both metrics. There was a four-fold difference for the $\mathrm{GR}_{50}$ (population 62 vs population 44) and a 3.8 fold difference for the $\mathrm{GR}_{90}$ (population 52 vs population 44). A dicamba use dose of $560 \mathrm{~g} \mathrm{ha}^{-1}$ provided greater than $90 \%$ reduction in dry weight for all populations (Table 2). 


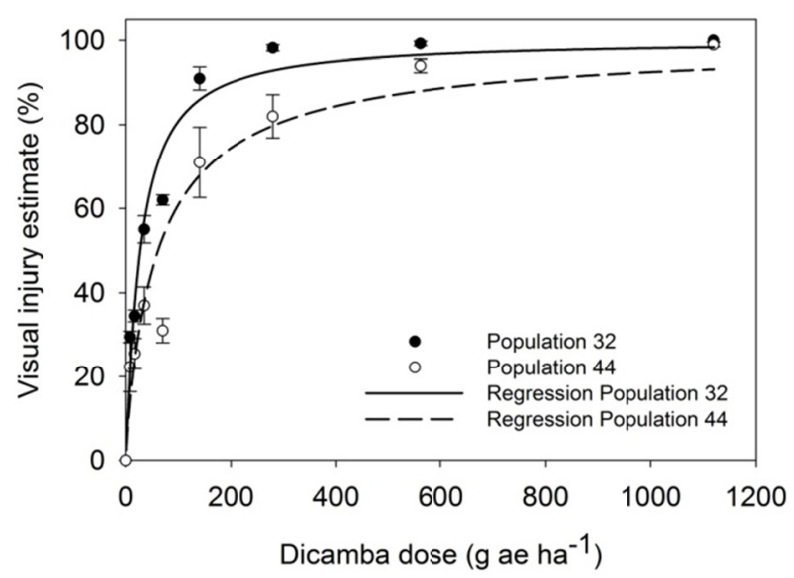

Figure 1. Effect of dicamba dose on visual injury estimate 28 DAT for the least (44) and most susceptible (32) horseweed populations. Data were fit using a log-logistic equation (Equation 1). Regression parameters are given in Table 1

\subsection{Effect of Dicamba on Horseweed Survival and Seed Production}

In our study, two replications of plants from five populations were allowed to grow up to 228 DAT to assess the effect of dicamba dose on survival and seed production (Tables 3). At 228 DAT all populations had individual plants that survived a dicamba dose of $70 \mathrm{~g} \mathrm{ha}^{-1}$ or greater (Table 3). Plants in populations 18 and 44 survived dicamba doses of $280 \mathrm{~g} \mathrm{ha}^{-1}$ and $140 \mathrm{~g} \mathrm{ha}^{-1}$, respectively (Table 3). Plants that survived to $228 \mathrm{DAT}$ also produced seed with the exception of population 32 which had a plant survive $70 \mathrm{~g} \mathrm{ha}^{-1}$, but the highest dose at which it set seed was $17 \mathrm{~g} \mathrm{ha}^{-1}$. Thus there was greater than a 10 fold difference in dicamba dose at which different populations produced seed. Population 18 produced seed at $280 \mathrm{~g} \mathrm{ha}^{-1}$ compared to populations 32 's maximum dose of $17 \mathrm{~g}$ ha $^{-1}$ (Table 3). Seed production ranged from 3400 to 30680 seeds per plant (Table 3).

Table 2. Dry weight regression parameters, $\mathrm{GR}_{50}, \mathrm{GR}_{80}$ and $\mathrm{GR}_{90}$ dicamba doses ( $\mathrm{g}$ ae ha ${ }^{-1}$ ), and standard errors (SE) at 28 DAT for ten horseweed populations from Nebraska. Regression parameters were estimated using a log-logistic equation (Equation 1)

\begin{tabular}{llllllllll}
\hline \multirow{2}{*}{ Population } & \multicolumn{9}{c}{ Regression parameters ${ }^{\mathrm{a}}$} \\
\cline { 2 - 7 } & $d$ & $c$ & $b$ & \multicolumn{3}{c}{$\mathrm{GR}_{50}( \pm \mathrm{SE})$} & $\mathrm{GR}_{80}( \pm \mathrm{SE})$ & \multirow{2}{*}{$\mathrm{GR}_{90}( \pm \mathrm{SE})$} \\
\hline 3 & 0.9 & 0.3 & 1.2 & 26 & $(8)$ & 84 & $(37)$ & 166 & $(103)$ \\
6 & 1.8 & 0.5 & 1.2 & 21 & $(6)$ & 70 & $(25)$ & 142 & $(72)$ \\
7 & 1.7 & 0.3 & 0.9 & 23 & $(5)$ & 99 & $(28)$ & 235 & $(96)$ \\
18 & 1.1 & 0.3 & 1.0 & 27 & $(7)$ & 109 & $(43)$ & 248 & $(142)$ \\
20 & 1.0 & 0.2 & 0.8 & 14 & $(5)$ & 86 & $(33)$ & 245 & $(145)$ \\
32 & 1.5 & 0.2 & 0.7 & 10 & $(4)$ & 66 & $(24)$ & 207 & $(121)$ \\
39 & 1.7 & 0.3 & 0.9 & 16 & $(4)$ & 74 & $(22)$ & 180 & $(79)$ \\
44 & 1.5 & 0.2 & 0.9 & 36 & $(8)$ & 175 & $(53)$ & 444 & $(194)$ \\
52 & 1.4 & 0.3 & 1.1 & 17 & $(3)$ & 57 & $(13)$ & 116 & $(40)$ \\
62 & 2.0 & 0.3 & 0.7 & 9 & $(5)$ & 72 & $(39)$ & 247 & $(212)$ \\
\hline R:S & & & & 4.0 & & 3.1 & & 3.8 & \\
\hline
\end{tabular}

${ }^{a}$ Regression parameters were estimated using a four parameter log-logistic equation (Equation 1), where, where $c$ represents the lower limit (minimum dry weight for each population), $d$ represents the upper limit (maximum dry weight for each population), $b$ represents the slope of the line at the inflection point, and $e$ represents the herbicide dose necessary to provide $50 \%$ reduction in dry matter $\left(\mathrm{GR}_{50}\right)$. 
Table 3. Number of seeds per plant and survival ${ }^{\text {a }}$ of five horseweed populations as affected by dicamba dose ( $g$ ae $\mathrm{ha}^{-1}$ ) at $228 \mathrm{DAT}$

\begin{tabular}{|c|c|c|c|c|c|c|c|c|c|c|}
\hline \multirow{2}{*}{ Dicamba dose } & \multicolumn{10}{|c|}{ Population } \\
\hline & $18^{\mathrm{b}}$ & & 20 & & 32 & & 39 & & 44 & \\
\hline 0 & $\$ 19450$ & $\mathrm{a}$ & $\$ 9810$ & $\mathrm{ab}$ & $\$ 16430$ & $\mathrm{a}$ & $\$ 30680$ & $\mathrm{a}$ & $\$ 18540$ & $a b$ \\
\hline 8 & $\$ 10990$ & $a b$ & $\$ 15640$ & $\mathrm{a}$ & $\$ 11340$ & $\mathrm{~b}$ & $\$ 16060$ & $\mathrm{~b}$ & $\$ 28110$ & $\mathrm{a}$ \\
\hline 17 & $\$ 13640$ & $a b$ & $\$ 4300$ & $\mathrm{bc}$ & $\$ 4720$ & $\mathrm{c}$ & $\$ 25310$ & $a b$ & $\$ 11730$ & $\mathrm{bc}$ \\
\hline 35 & $\$ 6850$ & $\mathrm{bc}$ & $\dagger 5190$ & $\mathrm{bc}$ & $* 0$ & $d$ & $\$ 10130$ & $\mathrm{bc}$ & $\$ 6580$ & $\mathrm{bc}$ \\
\hline 70 & $\$ 8900$ & $a b$ & $\dagger 3440$ & $\mathrm{bc}$ & $\dagger 0$ & $\mathrm{~d}$ & $\dagger 4960$ & $\mathrm{c}$ & $\$ 7610$ & $\mathrm{bc}$ \\
\hline 140 & $\uparrow 4130$ & $\mathrm{bc}$ & $* 0$ & $\mathrm{c}$ & $* 0$ & $\mathrm{~d}$ & $* 0$ & $\mathrm{c}$ & $\dagger 12050$ & $\mathrm{bc}$ \\
\hline 280 & $\dagger 5770$ & $\mathrm{bc}$ & $* 0$ & $\mathrm{c}$ & $* 0$ & $\mathrm{~d}$ & $* 0$ & $\mathrm{c}$ & $* 0$ & $\mathrm{c}$ \\
\hline 560 & $* 0$ & $\mathrm{c}$ & $* 0$ & $\mathrm{c}$ & $* 0$ & $\mathrm{~d}$ & $* 0$ & $\mathrm{c}$ & $* 0$ & $\mathrm{c}$ \\
\hline 1,120 & $* 0$ & $\mathrm{c}$ & $* 0$ & $\mathrm{c}$ & $*_{0}$ & $\mathrm{~d}$ & $* 0$ & $\mathrm{c}$ & $* 0$ & $\mathrm{c}$ \\
\hline
\end{tabular}

${ }^{a}$ Percent plant survival (of two replications) at 228 DAT: Seed numbers preceded by “ $\$$ ” had $100 \%$ survival; seed numbers preceded by " $\dagger$ " had 50\% survival; seed numbers preceded by "*” had $0 \%$ survival.

${ }^{\mathrm{b}}$ Mean values followed by the same letter in the same column are not significantly different $(\mathrm{p}<0.05)$.

\section{Discussion}

Manufacturers usually prescribe herbicide dosages large enough to ensure effective weed control over a broad range of species, management, and environmental conditions (Devlin, Long, \& Maddux, 1991), provided weeds are treated while below labeled sizes. But a common scenario is that farmers delay the herbicide application with the objective of controlling more weeds and reducing cost with a single application. The herbicide applied to larger weeds may result in an herbicide dose which is less than the labeled field dose (Terra, Martin, \& Lindquist, 2007). The recommended dosage for small, actively growing weeds with dicamba (i.e. Clarity ${ }^{\circledR}$ ) is 280 to $560 \mathrm{~g} \mathrm{ha}^{-1}$. Applying the labeled dosage should control most of the plants and minimize the risk that plants will survive to produce seed. If weeds are killed prior to producing seed, mutations that confer herbicide resistance are not important.

A previous study found a three- to four-fold range in horseweed tolerance to the diglycolamine salt of dicamba in Indiana (Kruger et al., 2010) which is similar to the results reported in our study in Nebraska. Kruger et al. (2010) reported that at least $300 \mathrm{~g} \mathrm{ha}^{-1}$ of dicamba should be applied for horseweed control under field conditions. Everitt and Keeling (2007) reported that dicamba doses of 140 and $280 \mathrm{~g} \mathrm{ha}^{-1}$ provided 93 and $98 \%$ control at 28 DAT, respectively, on horseweed populations from Texas treated in the rosette stage. In contrast, Wiese et al. (Wiese, Salisbury, \& Bean, 1995) reported only 57 and $75 \%$ control of horseweed treated at the rosette stage with labeled doses of 280 and $560 \mathrm{~g} \mathrm{ha}^{-1}$ of dicamba when plants were drought-stressed at the time of application.

Bell, Nalewaja and Schooler (1972) applied sublethal doses of 2,4-D to four consecutive generations of kochia which resulted in low level, multigenic resistance and a two-fold difference in susceptibility between the least and most susceptible lines. Similarly, Kruger et al. (2010) suggested horseweed populations may have the propensity to evolve to low-level 2,4-D resistance. The interaction of plant size and 2,4-D tolerance levels could enable less susceptible horseweed plants to survive and reproduce in the field following 2,4-D applications (Kruger et al., 2010). Neve and Powles (2004) demonstrated the potential for this to happen by crossing Lolium rigidum individuals that survived sublethal doses of diclofop-methyl, and over a period of three generations of selection with increasing herbicide doses developed a population resistant to the standard herbicide use dose. Gressel (2011) argued from a different perspective that low pesticide doses may enhance mutation doses and may hasten the development of resistant populations. Although our study did not address genetic differences among the horseweed populations evaluated, it is not unreasonable to predict that horseweed plants treated with sublethal doses of dicamba may survive and cross with other less susceptible plants in the population. Depending on the genetic mechanisms that confer this lack of susceptibility, populations with elevated tolerance to dicamba may evolve under repeated selection.

The plants that survived and produced seeds did so under controlled environmental conditions, with a single plant per pot and without competition from a crop or other weeds (Table 3). In field conditions, crop shading and plant 
density (i.e. crop and weeds) may influence survival and seed production. Bhowmik and Bekech (1993) showed that a single fall emerging horseweed plant can produce nearly 200000 seeds in no-tillage corn (Zea mays L.) stubble, grown at a horseweed density of 10 plants $\mathrm{m}^{-2}$, but $50 \%$ less seed at a horseweed density of 200 plants $\mathrm{m}^{-2}$. In general, the amount of seed produced by weeds that escape or survive herbicide applications is less than that of untreated weeds. For example, velvetleaf (Abutilon theophrasti Medic.) that escaped atrazine treatment produced $50 \%$ less seed than untreated plants (Schmenk \& Kells, 1998). When velvetleaf was treated with dicamba, the number of capsules per plant did not vary until the dicamba dose was $318 \mathrm{~g} \mathrm{ha}^{-1}$ or greater and then was closely related to biomass accumulation (Murphy \& Lindquist, 2002).

In summary, ten horseweed populations from southeastern Nebraska were screened with nine dicamba doses. The $\mathrm{I}_{90}$ exceeded $280 \mathrm{~g}_{\text {dicamba }} \mathrm{ha}^{-1}$ for five of the ten populations. Plants from two populations produced seed at a dose of $140 \mathrm{~g} \mathrm{ha}^{-1}$ or greater. Nevertheless, based on R:S ratios and recommended dicamba field use doses, none of the horseweed populations in this baseline study should be considered to be resistant to dicamba. However, there were individuals in the study that survived and produced seed when treated with doses of dicamba that may be considered "reduced doses" (140 $\mathrm{g} \mathrm{ha}^{-1}$ and less). As such, to minimize the risk of horseweed populations with reduced susceptibility to dicamba being selected in southeastern Nebraska, especially in horseweed populations already resistant to glyphosate, dicamba use doses of $560 \mathrm{~g} \mathrm{ha}^{-1}$ should be used and horseweed should be treated while in the rosette stage. Reduced doses or large plants at the time of application will increase the probability of individuals with decreased susceptibility surviving and producing seed that carries similar traits. In addition, rotating or tank-mixing different herbicides that are effective on horseweed with dicamba, and employing non-chemical control strategies such as tillage and crop rotation are essential to preserve the maximum utility of dicamba-resistant soybean for many years.

\section{Acknowledgments}

We appreciate the Nebraska Research Initiative for funding this research, and Rodrigo Werle, Leandro Manzano, Ana Wingeyer, Santiago Ulloa and Avishek Datta for technical assistance.

\section{References}

Behrens, M. R., Mutlu, N., Chakraborty, S., Dumitru, R., Jiang, W. Z., LaVallee, V. J., ... Weeks, D. P. (2007). Dicamba resistance: Enlarging and preserving biotechnology-based weed management strategies. Science, 316, 1185-1188. http://dx.doi.org/10.1126/science.1141596

Bell, A. R., Nalewaja, J. D., \& Schooler, A. B. (1972). Response of kochia selections to 2,4-D, dicamba, and picloram. Weed Sci, 20, 458-462.

Bhowmik, P. C., \& Bekech, M. M. (1993). Horseweed (Conyza canadensis) seed production, emergence, and distribution in no-tillage and conventional-tillage corn (Zea mays). Agron Trends Agric Sci, 1, 67-171.

Crespo, R. J., Bernards, M. L., \& Peterson, R. (2012). Perceived likelihood for weeds to evolve resistance to dicamba. Proc. North Central Weed Sci. Soc. Meeting. Saint Louis, MO. 67, 11.

Devlin, D. L., Long, J. H., \& Maddux, L. D. (1991). Using reduced rates of postemergence herbicides in soybeans (Glycine max). Weed Technol, 5, 834-840.

Everitt, J. D., \& Keeling, J. W. (2007). Weed control and cotton (Gossypium hirsutum) response to preplant applications of dicamba, 2,4-D, and diflufenzopyr plus dicamba. Weed Technol, 21, 506-510.

Gressel, J. (2011). Low pesticide rates may hasten the evolution of resistance by increasing mutation frequencies. Pest Manag Sci, 67, 253-257. http://dx.doi.org/10.1002/ps.2071

Heap, I. (2013). International survey of herbicide resistant weeds. Online. Retrieved January 28, 2013, from http://www.weedscience.org/In.asp

Johnson, S. R., Strom, S., \& Grillo, K. (2008). Quantification of the impacts on U.S. agriculture of biotechnology-derived crops planted in 2006. National Center for Food and Agricultural Policy, Washington, DC. Retrieved January 28, 2013, from http://www.ncfap.org/documents/2007biotech_report/Quantification_of_the_Impacts_on_US_Agriculture_ of_Biotechnology.pdf

Johnson, W. G, Young, B., Matthews, J., Marquardt, P., Slack, C., Bradley, K., ... \& Smeda, R. (2010). Weed control in dicamba-resistant soybeans. Crop Manag. http://dx.doi:10.1094/CM-2010-0920-01-RS

Kruger, G. R., Davis, V. M., Weller, S. C., \& Johnson, W. G. (2010). Control of horseweed (Conyza canadensis) with growth regulator herbicides. Weed Technol, 24, 425-429. http://dx.doi.org/10.1614/WT-D-10-00022.1 
Murphy, C. A., \& Lindquist, J. L. (2002). Growth response of velvetleaf to three postemergence herbicides. Weed Sci, 50, 364-369.

Neve, P., \& Powles, S. (2005). Recurrent selection with reduced herbicide rates in the rapid evolution of herbicide resistance in Lolium rigidum. Theor Appl Genet, 110, 1154-1166. http://dx.doi.org/10.1007/s00122-005-1947-2

Peterson, M. A., Simpson, D. M., Cui, C., Scherder, E. F., Ruen, D. C., Ellis, J. M., ... Wright, T. R. (2009). Performance of Dow Agrosciences herbicide tolerance trait in corn. Proc. North Central Weed Sci. Soc. Meeting. Kansas City, MO. 64, 11.

Schmenk, R., \& Kells, J. J. (1998). Effect of soil-applied atrazine and pendimethalin on velvetleaf (Abutilon theophrasti) competitiveness in corn. Weed Technol, 12, 47-52.

Simpson, D. M., Ruen, D. C., Scherder, E. F., Peterson, M. A., Ditmarsen, S. C., Ellis, J. M., ... Ellis, D. T. (2009). Performance of Dow Agrosciences herbicide tolerance trait in soybean. Proc. North Central Weed Sci. Soc. Meeting. Kansas City, MO., 64, 120.

Terra, B. R. M., Martin, A. R., \& Lindquist, J. L. (2007). Corn-velvetleaf (Abutilon theophrasti) interference is affected by sublethal doses of postemergence herbicides. Weed Sci, 55, 491-496.

VanGessel, M. J. (2001). Glyphosate-resistant horseweed from Delaware. Weed Sci, 49, 703-705.

Wiese, A. F., Salisbury, C. D., \& Bean, B. W. (1995). Downy brome (Bromus tectorum), jointed goatgrass (Aegilops cylindrica) and horseweed (Conyza canadensis) control in fallow. Weed Technol, 9, 249-254. 